\title{
An estimation of aerobic and anaerobic productivity of an organism of youth aged 17-19 years old of Podilsk region
}

\author{
Furman Yu.M. ${ }^{1 \mathrm{ABCDE}}$, Miroshnichenko V.M. ${ }^{\text {ABCDE }}$, Brezdeniuk O.Yu. ${ }^{2 \mathrm{ABDE}}$, Furman T.Yu. ${ }^{3 \mathrm{ABDE}}$ \\ ${ }^{1}$ Department of Biomedical Foundations of Physical Education and Physical Rehabilitation, Vinnytsia Mykhailo \\ Kotsiubynskyi State Pedagogical University, Ukraine; \\ ${ }^{2}$ Department of Physical Education, Vinnytsia Mykhailo Kotsiubynskyi State Pedagogical University, Ukraine \\ ${ }^{3}$ Vasyl' Stus Donetsk National University, Ukraine
}

Authors’ Contribution: A - Study design; B - Data collection; C - Statistical analysis; D - Manuscript Preparation; E - Funds Collection.

\begin{abstract}
Purpose: $\quad$ to establish standards for the assessment of the aerobic and anaerobic productivity of the body of youth aged 17-19 years old of the Podilsk region.

Material: $\quad$ The study involved students ( $\mathrm{n}=799$ - girls, $\mathrm{n}=668$ - boys). All students study at Higher Education Institutions of Vinnytsia (Ukraine) and live within Podilsk region. Students belong to the main medical group and have not been engaged in sports for the last 5 years.

Results: $\quad$ the criteria for evaluating the aerobic and anaerobic productivity of the organism of the youth of Podilsk region have been developed. The comparison of the individual values of students of Podilsk region with the standards of functional preparedness is carried out. The approaches to constructing an individual profile of students' functional readiness are determined. The profile visually distinguishes the sides of functional readiness, which require correction.

Conclusions: Standards for functional readiness need to be updated. New standards should be developed on the basis of the average of the indicator obtained as a result of the survey of a large number of persons of a uniform contingent. The gradation of standards is set within the range of the mean square deviation.

Keywords: functional preparedness, standards, youths, girls.
\end{abstract}

\section{Introduction}

The vast majority of scientific publications on the physiology of motor activity in recent decades indicate an inadequate level of functional preparedness of the population of Ukraine [1, 2].

There are no clearly defined recommendations for assessing the level of human functional preparedness. Apanasenko G.L. [3], Piarnat Ia.P. [4], Furman Y. [5] suggests to use an energy supply aerobic power process (VO2 max) for this purpose. This is due to the fact that in the total amount of energy potential of an organism, aerobic energy formation is largely anaerobic [6, 7]. Anaerobic processes of metabolism play an essential role in the formation of energy potential. With an increase in the level of anaerobic lactic productivity: the protection of the myocardium from hypoxia increases; lower plasma cholesterol and low density lipoprotein; increases the content of high density lipoprotein; the coefficient of atherogeny increases $[8,9]$. The study of the relationship between aerobic and anaerobic (lactate) productivity of the organism allowed to establish a strong correlation. Such a phenomenon is manifested only if: the factor is anaerobic productivity; the effective indicator is aerobic performance $[10,11]$. Therefore, the assessment of functional preparedness should be based on the aerobic and anaerobic potential of the organism.

There are no generally accepted criteria for evaluating human aerobic capacity. The data published by different authors is somewhat different. And most of the evaluation

\footnotetext{
(C) Furman Yu.M., Miroshnichenko V.M., Brezdeniuk O.Yu.,

Furman T.Yu, 2018
}

doi:10.15561/18189172.2018.0304 criteria apply to people over the age of 20. Exception is the evaluation criteria of Piarnat Ia.P. [4]. These criteria cover a wide age range (10 to 50 years). Such criteria do not take into account the features of the region.

Apanasenko G.L. [12] suggests evaluating aerobic performance at a "safe level of health", which is determined by the relative magnitude of $\mathrm{VO}_{2 \text { max }}$ (maximum oxygen consumption). For men, this level is $42.0 \mathrm{ml} \times \mathrm{min}^{-1} \times \mathrm{kg}$ ${ }^{-1}$. For women, this level is $35.0 \mathrm{ml} \times \mathrm{min}^{-1} \times \mathrm{kg}^{-1}$. Other studies indicate an excess of mean group values of the relative $\mathrm{VO}_{2 \max }$ at girls aged $17-19$ years old $[13,14]$. The average group of men the values of $\mathrm{VO}_{2 \max }$ are below the "safe level of health" $[11,15]$. The criteria for the "safe level of health" require clarification on the current state of health of the population of Ukraine.

To assess the aerobic capacity of the organism it is used a modified Kuper K. test [16]. The disadvantage of this technique is the lack of evaluation criteria that take into account the age of a person. Also, this technique does not take into account the differences in the region.

In addition to the power of aerobic energy supply, an important indicator of functional readiness is the threshold of anaerobic metabolism (TAM). This indicator reflects the capacity of aerobic energy supply processes [2]. Generally accepted standards for TAM evaluation do not exist. The TAM is evaluated by comparing the value of different individuals of the same sex and age group. Also, TAM estimates the dynamics of the values obtained from one person or group of individuals.

To determine the anaerobic performance of the

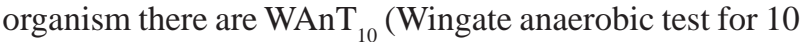
seconds), $\mathrm{WAnT}_{30}$ (Wingate anaerobic test for 30 seconds), 
MQMK (maximum quantity of mechanical work for 1 minute) tests [17]. We did not meet the evaluation criteria of anaerobic productivity in scientific sources. Therefore, anaerobic performance is evaluated in the same way as the capacity of aerobic performance.

Dulo O.A. and Furman Yu.M. [1] found the difference between the mean values of the aerobic and anaerobic productivity of the body of young people of all ages and sex in different regions of Ukraine. Therefore, there is a need to develop criteria that take into account the abovementioned factors.

All existing criteria for assessing the aerobic performance of an organism need to be updated taking into account the specifics of the region. In the absence of criteria for evaluating anaerobic productivity, there is a need for their development.

The developed criteria for assessing functional preparedness will become an objective benchmark for assessing the aerobic and anaerobic capabilities of the youth. Such criteria are based on modern data. They take into account the features of the region and reflect the entire spectrum of energy potential of the organism.

The purpose of the study is to establish standards for assessing the aerobic and anaerobic productivity of the body of youth in the age of 17-19 years of Podilsk region.

\section{Material and methods.}

Participants. The study involved students $(\mathrm{n}=799$ - girls, n = 668 - boys). All students study at Higher Education Institutions of Vinnytsia (Ukraine) and live within Podilsk region. Students belong to the main medical group and have not been engaged in sports for the last 5 years.

Organization of research. At first, the students determined the indicators of functional preparedness.

The power of aerobic energy supply processes was determined by Karpman V.L. et al [18]. The student performed two loads on a bicycle ergometer for 5 minutes each (interval of rest -3 minutes). The pedaling speed was 60 revolutions per min. ${ }^{-1}$. The power of the first load was $1 \mathrm{~W}$ per $1 \mathrm{~kg}$ of body weight. The power of the second load was $2 \mathrm{~W}$ per $1 \mathrm{~kg}$ of body weight. At the end of each load, the heart rate (heart rate) was recorded. The calculations were based on the value of $\mathrm{VO}_{2 \max } \cdot \mathrm{VO}_{2 \max }$ was displayed in $\mathrm{ml} \mathrm{min}^{-1}$.

TAM was determined by the test Yu.M. Furman [9]. The student performed work on a bicycle with a gradually increasing power. The duration of operation and the frequency of pedaling at each level did not change: the duration was $40 \mathrm{~s}$; the frequency was 60 revolutions per min. ${ }^{-1}$. The power of work was gradually increased. Work began at a power of $60 \mathrm{~W}$. $10 \mathrm{~W}$ were added per each degree. Every $40 \mathrm{~s}$ were determined by heart rate. The threshold of anaerobic exchange corresponded to the load capacity, which recorded the loss of linear growth of heart rate.

The capacity of anaerobic alactic productivity was determined by Wingate anaerobic test (Wingate anaerobic test for 10 seconds $-\mathrm{WAnT}_{10}$ ). The capacity of anaerobic lactic productivity was determined by Wingate anaerobic test (Wingate anaerobic test for 30 seconds - WAnT $_{30}$ ) [17]. These tests assume the performance of veloergometric load with the maximum possible frequency of pedaling: during $10 \mathrm{~s}$; within $30 \mathrm{~s}$. The magnitude of the capacity of anaerobic alactic productivity and anaerobic lactic productivity was reflected in $\mathrm{W}$ [17].

The capacity of anaerobic lactic energy supply processes was determined by the method of Shogy A., Cherebetin G [19]. This technique involves determining the maximum amount of external mechanical work for 1 min (maximum quantity of mechanical work for 1 minute - MQMK) when working on a bicycle. The magnitude of the capacity of anaerobic lactic energy supply processes was reflected in $\mathrm{W}$.

On the basis of the obtained data, the criteria for evaluation were developed.

The statistical analysis of the data was carried out using the Excel 2010 program.

The standards of functional readiness were developed on the basis of the arithmetic mean ( $\bar{X}$ ) of $\mathrm{VO}_{2 \max }$, TAM, $\mathrm{WAnT}_{10}, \mathrm{WAnT}_{30}, \mathrm{MQMK}$ and the range of mean square deviations $(\sigma)$.

\section{Results}

Tables $2-5$ show the standards of aerobic and anaerobic performance of the organism developed by us for the youth of 17-19 years old living in Podilsk region.

The data obtained by us confirmed the hypothesis that the "average' level of aerobic productivity of girls (see Table 1) is significantly higher than the established "safe level of health" [12]. For Piarnat Ia.P. [4] the "excellent" level of aerobic performance corresponds to a value $>38$ $\mathrm{ml} \times \mathrm{mil}^{-1} \times \mathrm{kg}^{-1}$. According to our data, the value of 38 $\mathrm{ml} \times \mathrm{min}^{-1} \times \mathrm{kg}^{-1}$ corresponds only to the "average" level (Table 1).

The standards of anaerobic body productivity of girls aged 17-19 years old do not have analogues in the literature, therefore it is impossible to compare them (Table 2).

The data in Table 3 indicates that the "average" level of aerobic productivity of 17-19 years old boys coincides with the "safe level of health" [12]. The data obtained are somewhat lower than the well-known standards for boys [4].

The standards of anaerobic productivity of the body of boys of 17-19 years old do not have analogues in the literature, therefore it is impossible to compare them (Table 2).

\section{Discussion.}

Dembo A.G. [20], Karpman V.L. [21] developed anthropometric standards. The authors, for an average level, took a range of $\pm 1 \sigma$ from the arithmetic mean for a large number of homogeneous contingents. Chogovadze A.V. [22] for the average level of the feature took the range $\pm 0,67 \sigma$. It is known that the value of $\pm 1 \sigma$ from $\bar{X}$ - is a fairly wide range. This range includes $68.27 \%$ of the total sample [23]. Therefore, we recommend a range of $\pm 0,5 \sigma$ 
Table 1. Standards of aerobic productivity of girls aged 17-19 years old in Podilsk region by indicators of VO and TAM, $(n=799)$

\begin{tabular}{|c|c|c|c|c|c|}
\hline Sigma & $\begin{array}{l}\text { Level of functional } \\
\text { preparation }\end{array}$ & 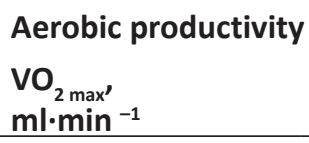 & 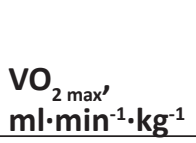 & $\begin{array}{l}\text { TAM, } \\
\text { W }\end{array}$ & $\begin{array}{l}\text { TAM, } \\
\mathbf{W} \cdot \mathrm{kg}^{-1} \\
\end{array}$ \\
\hline$>2,0 \sigma$ & Very high & $>2892,6$ & $>49,5$ & $>171,6$ & $>3,3$ \\
\hline $1,1-2,0 \sigma$ & high & $2658,6-2892,6$ & $44,9-49,5$ & $155,8-171,6$ & $2,8-3,3$ \\
\hline $0,6-1,0 \sigma$ & Above the average & $2541,7-2658,6$ & $42,46-44,8$ & $147,9-155,7$ & $2,7-2,8$ \\
\hline $\begin{array}{l}\bar{X}+0,5 \sigma- \\
(\bar{X} \pm 0,5 \sigma) \\
-\bar{X}-0,5 \sigma\end{array}$ & average & $\begin{array}{l}2541,6- \\
(2424,6 \pm 117,00) \\
-2307,6\end{array}$ & $\begin{array}{l}42,5- \\
(40,1 \pm 2,35) \\
-37,8\end{array}$ & $\begin{array}{l}147,8- \\
(139,8 \pm 7,96) \\
-131,8\end{array}$ & $\begin{array}{l}2,6- \\
(2,5 \pm 0,22) \\
-2,2\end{array}$ \\
\hline$-0,6--1,0 \sigma$ & Below the average & $2307,5-2190,6$ & $37,74-35,4$ & $131,7-123,9$ & $2,1-2,0$ \\
\hline$-1,1--2,0 \sigma$ & low & $2190,5-1956.6$ & $35,3-30,7$ & $123,8-107,9$ & $1,8-1,5$ \\
\hline$<-2,0 \sigma$ & Very low & $<1956.6$ & $<30,7$ & $<107,9$ & $<1,5$ \\
\hline
\end{tabular}

Note. $\square-$ average level of functional preparedness.

Table 2. Standards of anaerobic productivity of girls aged 17-19 years old in Podilsk region by WAnT ${ }_{10}(n=165)$, WAnT ${ }_{30}(n=165)$ and MQMK $(n=633)$

\begin{tabular}{|c|c|c|c|c|c|c|c|}
\hline \multirow[b]{2}{*}{ Sigma } & \multirow{2}{*}{$\begin{array}{l}\text { Level of } \\
\text { functional } \\
\text { preparation }\end{array}$} & \multicolumn{2}{|c|}{ Anaerobic productivity } & \multirow[b]{2}{*}{$\begin{array}{l}\text { WAnT }_{30^{\prime}} \\
\mathrm{kgm} \cdot \mathrm{min}^{-1}\end{array}$} & \multirow[b]{2}{*}{$\begin{array}{l}\text { WAnT }_{30} \\
\mathrm{kgm} \cdot \mathrm{min} \\
{ }^{-1} \cdot \mathrm{kg}^{-1}\end{array}$} & \multirow[b]{2}{*}{$\begin{array}{l}\text { MQMK, } \\
\mathrm{kgm} \cdot \mathrm{min}^{-1}\end{array}$} & \multirow[b]{2}{*}{$\begin{array}{l}\text { MQMK, } \\
\mathrm{kgm} \cdot \mathrm{min} \\
{ }^{-1} \cdot \mathrm{kg}^{-1}\end{array}$} \\
\hline & & $\begin{array}{l}\text { WAnT }_{10^{\prime}} \\
\mathrm{kgm} \cdot \mathrm{min}^{-1}\end{array}$ & $\begin{array}{l}\text { WAnT }_{10^{\prime}} \\
\mathrm{kgm} \cdot \mathrm{min}^{-1} \\
\cdot \mathrm{kg}^{-1}\end{array}$ & & & & \\
\hline$>2,0 \sigma$ & Very high & $>3398,8$ & $>49,42$ & $>2509,3$ & $>41,72$ & $>2171,2$ & $>34,5$ \\
\hline $1,1-2,0 \sigma$ & high & $\begin{array}{l}2845,2- \\
3398,8\end{array}$ & $\begin{array}{l}43,2- \\
49,42\end{array}$ & $\begin{array}{l}2110,7- \\
2509,3\end{array}$ & $\begin{array}{l}36,32- \\
41,72\end{array}$ & $\begin{array}{l}1947,3- \\
2171,2\end{array}$ & $\begin{array}{l}31,4- \\
34,5\end{array}$ \\
\hline $0,6-1,0 \sigma$ & $\begin{array}{l}\text { Above the } \\
\text { average }\end{array}$ & $\begin{array}{l}2568,3- \\
2845,1\end{array}$ & $\begin{array}{l}40,0- \\
43,1\end{array}$ & $\begin{array}{l}2110,6- \\
2309,8\end{array}$ & $33,7-36,31$ & $\begin{array}{l}1836,2- \\
1947,2\end{array}$ & $29,8-31,3$ \\
\hline $\begin{array}{l}\bar{X}+0,5 \sigma- \\
(\bar{X} \pm 0,5 \sigma)- \\
\bar{X}-0,5 \sigma\end{array}$ & average & $\begin{array}{l}2568,2- \\
(2291,3 \pm \\
276,87) \\
-2014,4\end{array}$ & $\begin{array}{l}39,9- \\
(36,8 \pm \\
3,11) \\
-33,7\end{array}$ & $\begin{array}{l}2110,5- \\
(1911,1 \pm \\
199,35) \\
-1711,8\end{array}$ & $\begin{array}{l}33,6- \\
(30,9 \pm \\
2,71) \\
-28,2\end{array}$ & $\begin{array}{l}1835,2- \\
(1723,2 \pm \\
112,01) \\
-1611,2\end{array}$ & $\begin{array}{l}29,7- \\
(28,1 \pm \\
1,55) \\
-26,6\end{array}$ \\
\hline$-0,6--1,0 \sigma$ & $\begin{array}{l}\text { Below the } \\
\text { average }\end{array}$ & $\begin{array}{l}2014,3- \\
1737,5\end{array}$ & $\begin{array}{l}33,6- \\
30,5\end{array}$ & $\begin{array}{l}1711,7- \\
1512,4\end{array}$ & $28,1-25,5$ & $\begin{array}{l}1611,1- \\
1499,2\end{array}$ & $\begin{array}{l}26,5- \\
25,1\end{array}$ \\
\hline$-1,1--2,0 \sigma$ & low & $\begin{array}{l}1737,4- \\
1183,8\end{array}$ & $\begin{array}{l}30,4- \\
24,3\end{array}$ & $\begin{array}{l}1512,3- \\
1113,7\end{array}$ & $25,4-20,1$ & $\begin{array}{l}1499,1- \\
1275,2\end{array}$ & $\begin{array}{l}25,0- \\
22,0\end{array}$ \\
\hline$<-2,0 \sigma$ & Very low & $<1183,7$ & $<24,3$ & $<1113,7$ & $<20,1$ & $<1275,2$ & $<22,0$ \\
\hline
\end{tabular}

Note.

- average level of functional preparedness.

to determine the average level of aerobic and anaerobic performance of an organism. The level "above average" or "below average" is recommended to be determined within the range $0,6 \sigma-1 \sigma$ or $(-0,6 \sigma)-(-1 \sigma)$. The "high" and "low" levels can be found within the range $1.1 \sigma-2 \sigma$ or $(-1.1 \sigma)-(-2 \sigma)$. The "very high" level should be found within> $2.0 \sigma$. The "very low" level should be found within the range of $<-2.0 \sigma$.

According to this concept: the standards of functional preparedness - this range of deviation from the average values of indicators of aerobic and anaerobic productivity of the organism. This range is expressed in $\sigma$. Such a range is obtained by statistical processing of a large number of measurements of a homogeneous composition of the contingent of people. This contingent does not differ by age, gender, social status, physical activity, or residence in a particular area.

We have compared the individual values of the students of Podilsk region with the standards of functional readiness (Fig. 1). In this way, we get an individual profile of functional preparadness. The profile visually distinguishes those aspects of functional 
Table 3. Standards of aerobic productivity of boys of the 17-19 years of the Podilsk region in terms of indicators $\mathrm{VO}_{2}$ $(n=668)$ and TAM $(n=482)$

\begin{tabular}{|c|c|c|c|c|c|}
\hline Sigma & $\begin{array}{l}\text { Level of functional } \\
\text { preparation }\end{array}$ & $\begin{array}{l}\text { Aerobic productivity } \\
\mathrm{VO}_{2 \max ^{\prime}} \\
\mathrm{ml} \mathrm{min}^{-1}\end{array}$ & $\begin{array}{l}\mathrm{VO}_{2 \text { max }^{\prime}} \\
\mathrm{ml}^{\prime} \mathrm{min}^{-1} \cdot \mathrm{kg}^{-1}\end{array}$ & $\begin{array}{l}\text { TAM, } \\
\mathbf{W}\end{array}$ & $\begin{array}{l}\text { TAM, } \\
\text { W kg }^{-1}\end{array}$ \\
\hline$>2,0 \sigma$ & Very high & $>3512,4$ & $>50,0$ & $>229,0$ & $>3,4$ \\
\hline $1,1-2,0 \sigma$ & high & $3263,9-3512,4$ & $45,9-50,0$ & $211,3-229,0$ & $3,1-3,4$ \\
\hline $0,6-1,0 \sigma$ & Above the average & $3139,5-3263,8$ & $43,8-45,8$ & $202,4-211,2$ & $2,74-3,0$ \\
\hline $\begin{array}{l}\bar{X}+0,5 \sigma- \\
(\bar{X} \pm 0,5 \sigma)- \\
\bar{X}-0,5 \sigma\end{array}$ & average & $\begin{array}{l}3139,4- \\
(3015,1 \pm 124,3) \\
-2890,8\end{array}$ & $\begin{array}{l}43,7- \\
(41,6 \pm 2,10) \\
-39,5\end{array}$ & $\begin{array}{l}202,3- \\
(193,4 \pm 8,9) \\
-184,5\end{array}$ & $\begin{array}{l}2,7- \\
(2,5 \pm 0,23) \\
-2,3\end{array}$ \\
\hline$-0,6--1,0 \sigma$ & Below the average & $2890,7-2766,4$ & $39,4-37,4$ & $184,4-175,6$ & $2,26-2,05$ \\
\hline$-1,1--2,0 \sigma$ & low & $2766,3-2517,8$ & $37,3-33,2$ & $175,5-157,8$ & $2,04-1,6$ \\
\hline$<-2,0 \sigma$ & Very low & $<2517,8$ & $<33,2$ & $<157,8$ & $<1,6$ \\
\hline
\end{tabular}

Note. $\square$ - average level of functional preparedness.

Table 4. Standards of anaerobic productivity of boys aged 17-19 years old in Podilsk region according to the indices of WAnT $_{10}(n=124)$, WAnT $_{30}(n=124)$ and MQMK $(n=548)$.

\begin{tabular}{|c|c|c|c|c|c|c|c|}
\hline \multirow[b]{2}{*}{ Sigma } & \multirow{2}{*}{$\begin{array}{l}\text { Level of } \\
\text { functional } \\
\text { preparation }\end{array}$} & \multicolumn{2}{|c|}{ Anaerobic productivity } & \multirow[b]{2}{*}{$\begin{array}{l}\text { WAnT }_{30^{\prime}} \\
\mathrm{kgm} \cdot \mathrm{min} \\
-1\end{array}$} & \multirow[b]{2}{*}{$\begin{array}{l}\text { WAnT }{ }_{30^{\prime}} \\
\mathrm{kgm} \cdot \mathrm{min}^{-1} \\
\cdot \mathrm{kg}^{-1}\end{array}$} & \multirow[b]{2}{*}{$\begin{array}{l}\text { MQMK, } \\
\mathrm{kgm} \cdot \mathrm{min} \\
-1\end{array}$} & \multirow[b]{2}{*}{$\begin{array}{l}\text { MQMK, } \\
\mathrm{kgm} \cdot \mathrm{min} \\
{ }^{-1} \cdot \mathrm{kg}^{-1}\end{array}$} \\
\hline & & $\begin{array}{l}\text { WAnT } \\
{ }_{10}^{\prime} \\
\mathrm{kgm} \cdot \mathrm{min}^{-1}\end{array}$ & $\begin{array}{l}\text { WAnT }_{10^{\prime}} \\
\mathrm{kgm} \cdot \mathrm{min}^{-1} \\
\cdot \mathrm{kg}^{-1}\end{array}$ & & & & \\
\hline$>2,0 \sigma$ & Very high & $>5064,8$ & $>68,3$ & $>4891,9$ & $>63,72$ & $>2853,2$ & $>42,2$ \\
\hline $1,1-2,0 \sigma$ & high & $\begin{array}{l}4510,8- \\
5064,8\end{array}$ & $61,6-68,3$ & $\begin{array}{l}4246,7- \\
4891,9\end{array}$ & $56,8-63,72$ & $\begin{array}{l}2582,2- \\
2853,2\end{array}$ & $37,3-42,2$ \\
\hline $0,6-1,0 \sigma$ & $\begin{array}{l}\text { Above the } \\
\text { average }\end{array}$ & $\begin{array}{l}4233,8- \\
4510,7\end{array}$ & $58,2-61,5$ & $\begin{array}{l}3924,0- \\
4246,6\end{array}$ & $53,4-56,7$ & $\begin{array}{l}2446,7- \\
2582,1\end{array}$ & $34,9-37,2$ \\
\hline $\begin{array}{l}\bar{X}+0,5 \sigma- \\
(\bar{X} \pm 0,5 \sigma)- \\
\bar{X}-0,5 \sigma\end{array}$ & average & $\begin{array}{l}4233,7- \\
(3956,6 \pm \\
277,05) \\
-3679,6\end{array}$ & $\begin{array}{l}58,1- \\
(54,7 \pm \\
3,40) \\
-51,3\end{array}$ & $\begin{array}{c}3923,9- \\
(3601,2 \\
\pm 322,69) \\
-3278,5\end{array}$ & $\begin{array}{l}53,3- \\
(49,8 \pm \\
3,48) \\
-46,3\end{array}$ & $\begin{array}{c}2446,6- \\
(2311,0 \\
\pm 135,56) \\
-2175,4\end{array}$ & $\begin{array}{l}34,8- \\
(32,3 \pm \\
2,47) \\
-29,8\end{array}$ \\
\hline$-0,6--1,0 \sigma$ & $\begin{array}{l}\text { Below the } \\
\text { average }\end{array}$ & $\begin{array}{l}3679,5- \\
3402,5\end{array}$ & $51,2-47,9$ & $\begin{array}{l}3278,5- \\
2955,8\end{array}$ & $46,2-42,8$ & $\begin{array}{l}2175,3- \\
2039,9\end{array}$ & $29,8-27,4$ \\
\hline$-1,1--2,0 \sigma$ & low & $\begin{array}{l}3402,4- \\
2848,4\end{array}$ & $47,8-41,1$ & $\begin{array}{l}2955,7- \\
2310,5\end{array}$ & $42,7-35,9$ & $\begin{array}{l}2039,8- \\
1768,8\end{array}$ & $27,3-22,4$ \\
\hline$<-2,0 \sigma$ & Very low & $<2848,4$ & $<41,1$ & $<2310,5$ & $<35,9$ & $<1768,8$ & $<22,4$ \\
\hline
\end{tabular}

Note. - average level of functional preparedness.

readiness that require correction. As an example of the functional readiness of student $\mathrm{N}$. The level of functional preparedness is within the range or exceeds it. According to the level of functional readiness of the student, one can conclude that the means of physical education should be directed to maintain its level of functional readiness.

\section{Conclusions.}

It is known that over time the standards of functional readiness lose their objectivity. Therefore, such standards need to be updated. In literary sources, there are no standards for functional preparedness in terms of TAM, anaerobic lactic and anaerobic alactic productivity of the organism. We have found that new standards are developed by the average of the indicator. For this purpose, a survey of a large number of people of a uniform contingent is conducted. The gradation of standards is set within the range of the mean square deviation - $\sigma$. The developed standards cover the entire spectrum of aerobic and anaerobic productivity indicators of youth aged 17-19 


\begin{tabular}{|c|c|c|c|c|c|c|c|c|c|c|c|}
\hline \multirow[b]{2}{*}{ 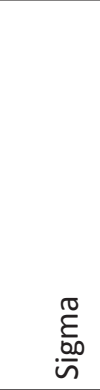 } & \multirow[b]{2}{*}{ 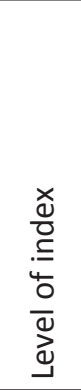 } & \multicolumn{4}{|c|}{$\begin{array}{l}\text { Indicators of aerobic } \\
\text { productivity }\end{array}$} & \multicolumn{6}{|c|}{ Indicators of anaerobic productivity } \\
\hline & & 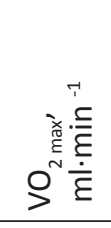 & 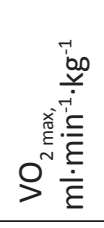 & $\begin{array}{l}3 \\
\sum_{\leqslant}\end{array}$ & 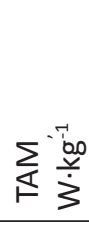 & 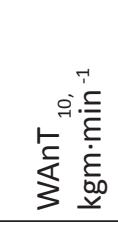 & 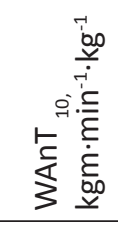 & 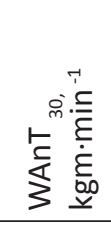 & 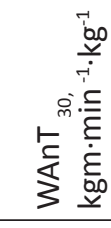 & 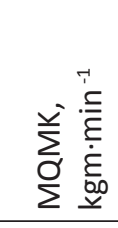 & 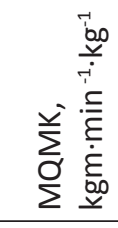 \\
\hline \multirow{2}{*}{$2,0 \sigma$} & $\begin{array}{l}\frac{c}{00} \\
\frac{.00}{2} \\
\frac{1}{10} \\
>\end{array}$ & & & & & & & & & & \\
\hline & $\frac{c}{.00}$ & 184,0 & 4,7 & 15.9 & 0,4 & 553,7 & 6,22 & 398,7 & 5,4 & 224,0 & 3,1 \\
\hline $0,5 \sigma$ & $\frac{3}{\frac{0}{\pi}} \sum_{\frac{\pi}{\pi}}^{\frac{0}{\pi}}$ & & & & & & & & & & \\
\hline $\bar{x}$ & & $24 \angle 4,6$ & & & 2,5 & & & & & & \\
\hline & $\stackrel{\pi}{\pi}_{\frac{\pi}{\pi}}^{\frac{\pi}{\pi}}$ & & 40,1 & & & 2291,3 & 36,8 & 1911,1 & 30,9 & 1723,2 & 28,1 \\
\hline$-1,0 \sigma$ & 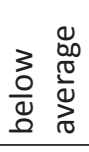 & & & & & & & & & & \\
\hline & $\underline{\text { zo }}$ & & & & & & & & & & \\
\hline-70 & $\frac{3}{\frac{3}{3}}$ & & & & & & & & & & \\
\hline
\end{tabular}

Fig. 1. Graphic representation of functional preparadness (individual profile) of examined N:

\footnotetext{
2424.6 - average value of index $(\overline{\mathrm{X}})$;

184.0 - average level of index;

- value $\sigma$.
}

years old in Podilsk region.

Further research should be directed to the development of a computer program that evaluates individual student data on the basis of standards developed by us.

\section{Acknowledgment}

This work is carried out in accordance with the plan of research work of the Department of Medical and Biological Foundations of Physical Education and Physical Rehabilitation of Vinnytsia Mykhailo
Kotsiubynskyi State Pedagogical University on the theme 9027 "Optimization of the process of improving the physical and functional preparedness of students and students in physical activity of different directions" (registration number 0113U007491)

\section{Conflict of interest.}

The authors state that there is no conflict of interest. 


\section{References}

1. Dulo OA, Furman YuM. Comparative characteristics of aerobic productivity of girls with different somatotype, living in mountainous and lowland areas of Zakarpattia. Biomedical and Biosocial Anthropology, 2013; 20:23-26. (in Ukrainian)

2. Furman YM, Miroshnichenko VM, Drachuk SP. Perspective models of physical culture and health technologies in physical education of students of higher educational establishments. Kiev, Olympic Literature; 2013; 184. (in Ukrainian)

3. Apanasenko GL, Popova LA, Magl'ovanij AV. Sanology, Lviv; 2011. (in Ukrainian)

4. Piarnat IaP. Age-sex standards (10-50 years) of human aerobic capacity. Dokt. Diss., Moscow; 1983. (in Russian)

5. Furman Y, Brezdeniuk O. Influence of run workloads in a mixed energy supply mode upon functional preparedness of students with a "high" fat component content. Physical education, sports and health in modern society, 2017; 1(37):52 - 58.

6. Cooper K. Running without fear. New York; 1985.

7. Filippov MM. Features of oxygen regimes of the body of athletes in the mountains. Fiziologichnij zhurnal. 2008; 54(4):94. (in Ukrainian)

8. Pirogova EA, Ivashchenko LIa, Strapko NP. Influence of physical exercises on the efficiency and health of a person. Kiev: Health; 1986. (in Russian)

9. Furman YM. Correction of aerobic and anaerobic lactic productivity of an organism of young people by running loads of different regimes. Dokt. Diss.. Kiev; 2003. (in Ukrainian)

10.Del Rosso S, Nakamura FY, Boullosa DA. Heart rate recovery after aerobic and anaerobic tests: is there an influence of anaerobic speed reserve? Journal of Sports Sciences. 2017;35(9):820-827. doi:10.1080/02640414.2016.1166391

11.Frikha M, Chaari N, Mezghanni N, Souissi N. Influence of warm-up duration and recovery interval prior to exercise on anaerobic performance. Biology of Sport. 2016;33(4):361366. doi:10.5604/20831862.1221830
12.Apanasenko GL. Selected articles about health. Kiev; 2005. (in Russian)

13.Furman YuM, Miroshnichenko VM. Characteristics of physical health of girls of different somatotype in the postpubber development period. Fiziologichnij zhurnal. 2006; 52(2):156 - 157. (in Ukrainian)

14.Brezdeniuk O. Aerobic possibilities of 17-21 year students with different components of body mass. Fizichna aktivnist', zdorov'ia i sport, 2014;1:9-18. (in Ukrainian)

15.Bichay AAF, Ramirez JM, Nunez VM, Lancho C, Poblador MS, Lancho JL. Efficacy of treadmill exercises on arterial blood oxygenation, oxygen consumption and walking distance in healthy elderly people: a controlled trial. BMC Geriatrics. 2016;16. doi:10.1186/s12877-016-0283-5

16.Kuper K. Aerobics for well-being. Moscow: Physical Culture and Sport; 1989. (in Russian)

17.Inbar O, Bar-Or O, Skinner JS. The Wingate anaerobic test: development and application. IL: Human Kinetics; 1996.

18.Karpman VL, Belocerkovckij ZB, Gudkov IL. The study of physical performance in athletes. Moscow: Physical Culture and Sport; 1974. (in Russian)

19.Shögy A, Cherebetin G. Minutentest aufdem fanradergometer zur bestimmung der anaeroben Kapazität [Minute test on the fanradergometer to determine the anaerobic capacity.]. Eur. J. Appl. Physiol. 1974;33:171-176. (In German)

20.Dembo AG. Popov SN, Teslenko ZhA, Shapkajc IuM. Sports medicine. Moscow: Physical Culture and Sport; 1975. (in Russian)

21.Karpman VL. Testing in diagnostics of physical working capacity and functional readiness of athletes. Moscow: Physical Culture and Sport; 1987. (in Russian)

22.Chogovadze AV, Butchenko LA. Sports medicine. Moscow: Medicine; 1984. (in Russian)

23.Denisova LV, Khmel'nickaia IV, Harchenko LA. Measurements and methods of mathematical statistics in physical education and sport. Kiev: Olympic Literature; 2008. (in Russian)

\section{Information about the authors:}

Furman Yu.M.; http://orcid.org/0000-0002-5206-7712; Vinnytsia Mykhailo Kotsiubynskyi State Pedagogical University; Ostroz'koho st., 32, Vinnytsia, 21100, Ukraine.

Miroshnichenko V.M.; http://orcid.org/0000-0003-1139-4554; Vinnytsia Mykhailo Kotsiubynskyi State Pedagogical University; Ostroz'koho, st. 32, Vinnytsia, 21100, Ukraine.

Brezdeniuk O.Y. (Corresponding author); http://orcid.org/0000-0003-0844-8777; sandrikk86@gmail.com; Vinnytsia Mykhailo Kotsiubynskyi State Pedagogical University; Ostroz'koho st., 32, Vinnytsia, 21100, Ukraine.

Furman T.Yu.; http://orcid.org/0000-0002-8515-6674; Vasyl' Stus Donetsk National University, Ukraine; 21, 600-richya str., Vinnytsia, 21021, Ukraine.

Cite this article as: Furman Yu.M., Miroshnichenko V.M., Brezdeniuk OYu, Furman TYu. An estimation of aerobic and anaerobic productivity of an organism of youth aged 17-19 years old of Podilsk region. Pedagogics, psychology, medical-biological problems of physical training and sports, 2018;22(3):136-141. doi:10.15561/18189172.2018.0304

The electronic version of this article is the complete one and can be found online at: http://www.sportpedagogy.org.ua/index.php/PPS/issue/archive

This is an Open Access article distributed under the terms of the Creative Commons Attribution License, which permits unrestricted use, distribution, and reproduction in any medium, provided the original work is properly cited (http://creativecommons.org/licenses/by/4.0/deed.en).

Received: 12.12 .2017

Accepted: 20.01.2018; Published: 30.06.2018 